Reprod. Nutr. Dévelop., 1981, 21 (6B), 1113-1124.

\title{
Predicting the adult daily sperm output after the first ejaculates in cockerels raised under different photoschedules
}

\author{
by $M$. de REVIERS, J. WILLIAMS \\ with the technical assistance of Maryse GARREAU and J. P. BRILLARD
}

Summary. In M33 cockerels, the rapid phase of testicular growth and the onset of sperm production were advanced either by increasing daylengths or an interrupted-night photoschedule ; they were delayed by consiant short days $(8 \mathrm{~L})$. The results observed under constant long days (16L) were intermediate. In this strain, the cockerels maintained their mean testicular weight during the adult period while their daily sperm output (DSO) gradually declined.

Individual variations in the DSO results were greater than individual variations in testicular weight. These variations did not appear to be influenced by the photoschedules. The differences in DSO observed between the best and the worst semen donors at the end of testicular development or thereafter remained relatively stable in ageing cockerels, except in birds submitted to increased photoperiods. This is the basis of the method described here for reliably choosing the best semen donors just before they are used as breeders.

\section{Introduction.}

In the cockerel as in other domesticated male birds, adult testis weight and sperm production, even when determined in birds of the same age raised under the same conditions, are known to vary considerably between individual cockerels of the same strain or cross.

The purpose of this study was to precisely characterize and compare the individual variations in these parameters in the same strain of cockerel under various photoschedules. The final aim was to test the feasibility of a method of selecting future breeders, based on their sperm production before the sexual maturity of the hen with which they are to be mated.

Petitjean et al. (1978) were previously able to perform this selection in Wyandotte M11 cockerels using motility scores as predictors, but did not give any indication either of the age of the cockerels at the time of their selection or of the rearing conditions. The present paper deals with testicular weight gain and development and the numerical aspects of sperm production.

\section{Materials and methods.}

Medium-heavy M33 strain cockerels (adult weight : $3.5 \mathrm{~kg}$ ) were raised from hatching under the same standard conditions except for the artificial lighting schedules. 
These schedules, elaborated as a result of previous experiments on testicular development (de Reviers, 1980), were as follows (see also fig. 1a, b) :

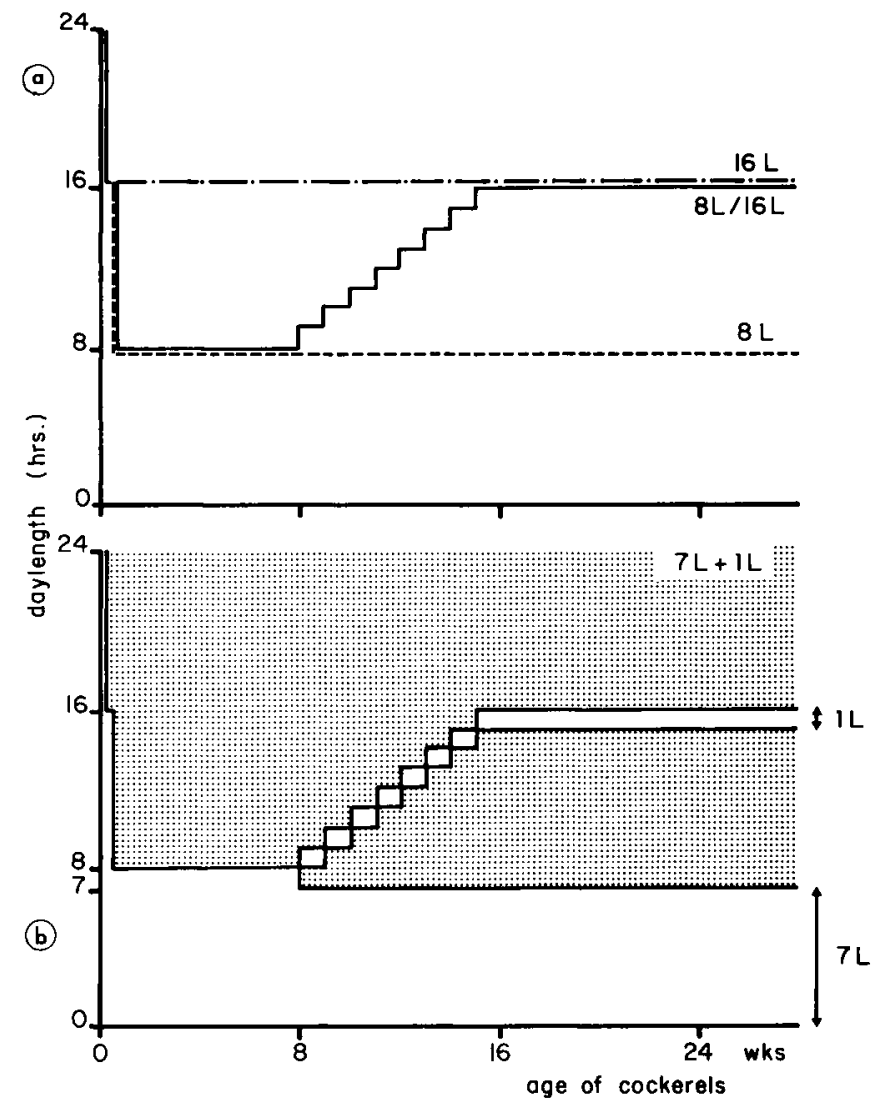

FIG. 1. - Diagrammatical representation of the experimental photoschedules applied to M33 cockerels. Continuous light was applied from hatch to 3 days, then the photoperiod was reduced to $16 \mathrm{~L} / 8 \mathrm{D}$ in all cases. In the $16 \mathrm{~L}$ group, it was maintained at that level. In the other groups, a further change was made at 7 days of age : $8 \mathrm{~L}$ group : reduction to $8 \mathrm{~L} / 16 \mathrm{D} ; 8 \mathrm{~L} / 16 \mathrm{~L}$ : reduction to $8 \mathrm{~L} / 16 \mathrm{D}$, with increases in the photoperiod applied later as shown; $7 \mathrm{~L}+1 \mathrm{~L}$ : reduction to $8 \mathrm{~L} / 16 \mathrm{D}$, with a secondary $1 \mathrm{~h}$ photoperiod applied later as shown. Note that the extinction of this secondary photoperiod coincided with the extinction of light in the $8 \mathrm{~L} / 16 \mathrm{~L}$ group. Hatched zone corresponds to lights off.

1) $16 \mathrm{~h}$ of light $(L)+8 \mathrm{~h}$ of darkness (D) daily from 3 days of age to the end of the experiment (53 weeks of age). Referred to here as the $16 \mathrm{~L}$ group.

2) $16 \mathrm{~L}: 8 \mathrm{D}$ from days 4 to 7 then $8 \mathrm{~L}: 16 \mathrm{D}$ from 1 to 53 weeks of age. Referred to here as the $8 \mathrm{~L}$ group. 
3) As above until 8 weeks of age, then the daily photoperiod was gradually increased to $16 \mathrm{~L}: 8 \mathrm{D}(+1 \mathrm{~L}$ each week) which was reached at the 15 th week of age. Referred to here as the $8 \mathrm{D} / 16 \mathrm{~L}$ group.

4) As in 2 until 8 weeks of age. Thereafter, the cockerels were submitted to an interrupted-night photoschedule referred to here as $7 \mathrm{~L}+1 \mathrm{~L}$. The $1 \mathrm{~L}$ photoperiod was shifted weekly from 8 to 15 weeks of age, its extinction being maintained at the same time as under $8 \mathrm{~L} / 16 \mathrm{~L}$ (fig. $1 \mathrm{~b}$ ).

During the first 3 days following hatch, all animals were subjected to continuous lighting.

The femperature was $32^{\circ} \mathrm{C}$ at hatching, then decreased by $2^{\circ} \mathrm{C} /$ week until 6 weeks of age, and maintained at $20 \pm 1{ }^{\circ} \mathrm{C}$ thereafter.

All animals were given free access to water and fed ad libitum (all mash ration, $M E=2800 \mathrm{kcal} / \mathrm{kg}$, crude protein : $17 \mathrm{p} .100$ from hatching until 6 weeks of age, then 14 p. 100).

The experimental work involved two trials :

In experiment 1, 4 batches of 80 cockerels each were respectively submitted to the 4 photoschedules described above. At various ages from 12 to 44 weeks, 10 cockerels from each group were killed and their testes weighed to the nearest $\mathrm{mg}$. In this experiment, the trials using photoschedules $16 \mathrm{~L}, 8 \mathrm{~L}$ and $7+1 \mathrm{~L}$ were duplicated over two consecutive years (Exp. $1 a$ and $1 b$ ).

In experiment 2, another 4 batches of 30 cockerels each were respectively raised under the same conditions. Their semen was collected daily (except on Saturdays and Sundays) from 18 to 24 weeks of age, then at 32-33, 40 and 51-52 weeks of age. Over 7000 ejaculates were analyzed during the experimental period. All ejaculates were collected by the same person to eliminate bias due to the semen collection technique.

Prior to each collection period, the cockerels were ejaculated daily for 1 week to stabilize the sperm reserves of the deferent ducts.

This semen collection frequency was designed to enable us to estimate the nearest approximation to the daily sperm production (de Reviers, 1972b).

The volume of ejaculates (estimated by weighing the semen which had a specific gravity of nearly $1 \mathrm{~g} / \mathrm{ml}$ ) and their sperm concentration (estimated by optical density of semen diluted $1: 100, \lambda=650 \mathrm{~nm}$ ) were individually recorded to calculate the total number of sperms per ejaculate. This was expressed as the DSO (Amann,1970), i.e. the total number of sperm collected over a given period of time and expressed on a per-day basis.

\section{Results.}

1. Growth of the testes (Experiment 1).

The mean values of testicular weight amplitude and their coefficients of variation are summarized in table 1 and fig. 2.

Under constant daily photoperiods ( $16 \mathrm{~L}$ or $8 \mathrm{~L}$ ), the rapid phase of testicular growth occurred between 16 and 24 weeks of age. Some reduction in mean testicular weight 
was observed thereafter under $16 \mathrm{~L}$ while it was maintained at approximately the same level under $8 \mathrm{~L}$.

The rapid phase of testicular growth occurred somewhat earlier under the $8 \mathrm{~L} / 16 \mathrm{~L}$ and $7 \mathrm{~L}+1 \mathrm{~L}$ photoschedules than under constant daily photoperiods. This difference, however, was not statistically significant at the $5 \mathrm{p}$. 100 level because of the wide individual variations observed at 16 weeks of age in the testis weights and because of the small size of the experimental groups. At 24 weeks of age the mean testis weight observed under the $8 \mathrm{~L} / 16 \mathrm{~L}$ photoschedule was the same as under the $7 \mathrm{~L}+1 \mathrm{~L}$ photoschedule $(7 \mathrm{~L}+1 \mathrm{~L}, 8 \mathrm{~L} / 16 \mathrm{~L}, 16 \mathrm{~L} ; 18.3 \mathrm{~g}, 14.0 \mathrm{~g}, 14.6 \mathrm{~g}$ respectively). Thereafter, some reduction was observed in testicular weights under both the $8 \mathrm{~L} / 16 \mathrm{~L}$ and the $7 \mathrm{~L}+1 \mathrm{~L}$ photoschedules, but the mean weight was still higher under $7 \mathrm{~L}+1 \mathrm{~L}$ than under $8 \mathrm{~L} / 16 \mathrm{~L}$ at 28 weeks of age 15.4 vs $10.9 \mathrm{~g}$ respectively.

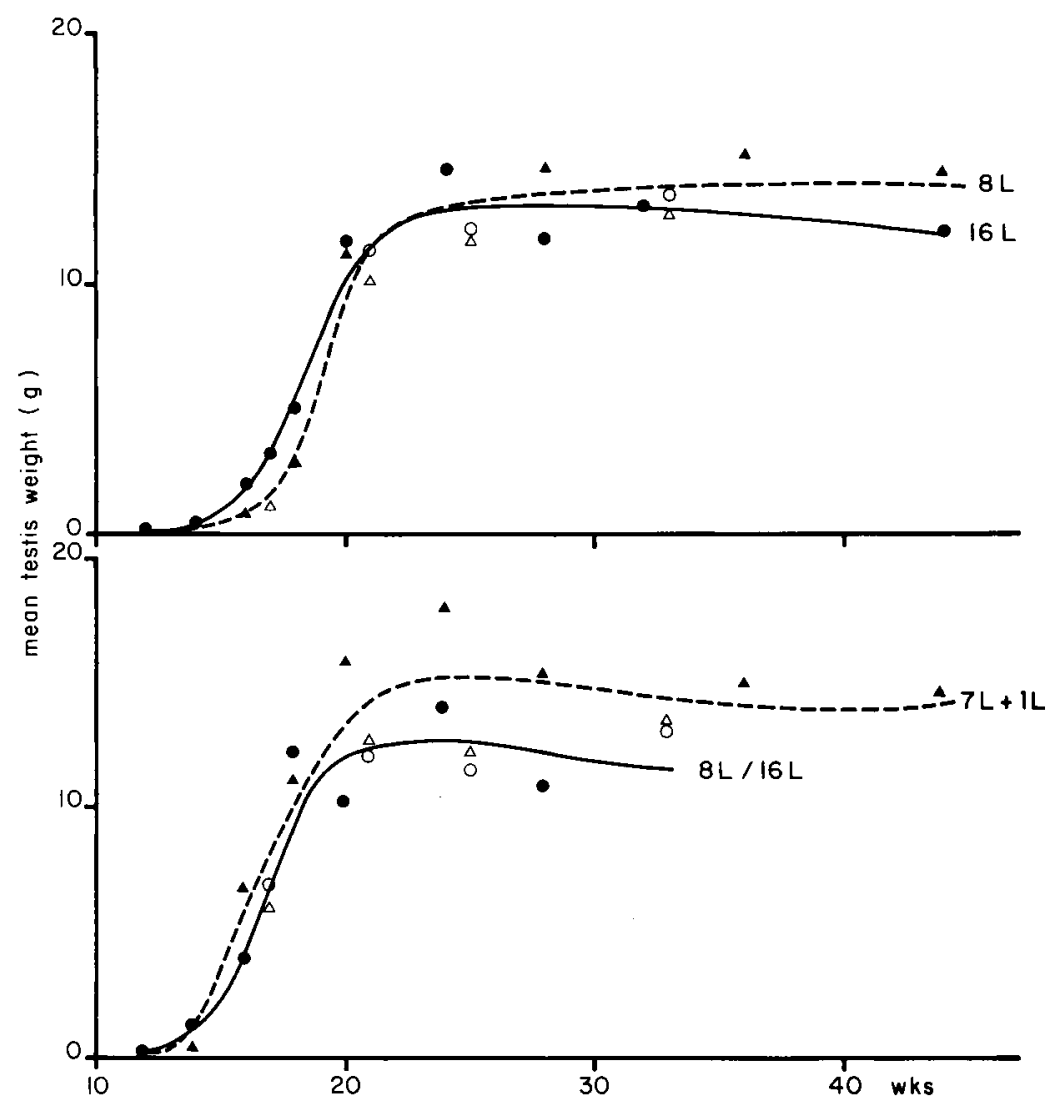

FIG. 2. - Mean festicular weights observed under the various experimental photoschedules. Datai rom two consecutive trials (open vs closed symbols). A short lag occurred between the phases of rapid testicular growth in 16L and $8 \mathrm{~L}$ cockereis. This phase of growth intervened earlier in birds subjected to $8 \mathrm{~L} / 16 \mathrm{~L}$ or $7 \mathrm{~L}+1 \mathrm{~L}$. Note that the mean testicular weight is maintained after the end of testicular development. See table 1 for individual variations. Keys : Upper panel : circles $=16 \mathrm{~L}$, triangles $=8 \mathrm{~L}$. - Lower panel : circles $=8 \mathrm{~L} / 16 \mathrm{~L}$, triangles $=7 \mathrm{~L}+1 \mathrm{~L}$. 
TABLE 1

Mean, range and coefficient of variotion of the testicular weights observed in M33 cockerels raised under various photoschedules

\begin{tabular}{|c|c|c|c|c|c|c|}
\hline \multirow{2}{*}{ Photoschedule } & \multirow{2}{*}{ Parameter } & \multicolumn{5}{|c|}{ Age in weeks } \\
\hline & & 12 & 16 & 24 & 28 & 44 \\
\hline $16 \mathrm{~L}: 8 \mathrm{D}$ & $\begin{array}{l}\text { Mean }(g) \ldots \ldots \ldots \\
\text { Range }(g) \ldots \ldots \ldots \\
\text { C.V. . } 100 \ldots \ldots\end{array}$ & $\begin{array}{c}0.27 \\
0.15-0.45 \\
39\end{array}$ & $\begin{array}{c}2.1 \\
0.41-4.01 \\
94\end{array}$ & $\begin{array}{c}14.6 \\
10.2-18.2 \\
22\end{array}$ & $\begin{array}{l}11.8 \\
8-16.3 \\
22\end{array}$ & $\begin{array}{c}12.2 \\
9.5-16.8 \\
18\end{array}$ \\
\hline $8 \mathrm{~L}: 16 \mathrm{D}$ & $\begin{array}{l}\text { Mean }(g) \ldots \ldots \ldots \\
\text { Range }(g) \ldots \ldots \\
\text { C.V. p. } 100 \ldots \ldots\end{array}$ & $\begin{array}{c}0.24 \\
0.17-0.35 \\
22\end{array}$ & $\begin{array}{c}1.13 \\
0.28-6.35 \\
167\end{array}$ & $\begin{array}{c}14.3 \\
8.7-16.9 \\
16\end{array}$ & $\begin{array}{c}14.8 \\
11.6-17.3 \\
14\end{array}$ & $\begin{array}{c}15.3 \\
9.9-19.6 \\
19\end{array}$ \\
\hline $\begin{array}{l}8 \mathrm{~L}: 16 \mathrm{D} \text { to } \\
16 \mathrm{~L}: 8 \mathrm{D}\end{array}$ & $\begin{array}{l}\text { Mean }(g) \ldots \ldots \ldots \\
\text { Range }(g) \ldots \ldots \ldots \\
\text { C.V. p. } 100 \ldots \ldots\end{array}$ & $\begin{array}{c}0.25 \\
0.19-0.31 \\
18\end{array}$ & $\begin{array}{c}4.02 \\
0.83-8.48 \\
49\end{array}$ & $\begin{array}{c}14.0 \\
10.6-20.6 \\
22\end{array}$ & $\begin{array}{c}10.9 \\
6.0-16.9 \\
29\end{array}$ & - \\
\hline $7 L+1 L$ & $\begin{array}{l}\text { Mean }(g) \ldots \ldots \ldots \\
\text { Range }(g) \ldots \ldots \ldots \\
\text { C.V. p. } 100 \ldots \ldots\end{array}$ & $\begin{array}{c}0.19 \\
0.11-0.25 \\
23\end{array}$ & $\begin{array}{l}7.09 \\
4.2-10.9 \\
32\end{array}$ & $\begin{array}{c}18.3 \\
14.1-22.9 \\
14\end{array}$ & $\begin{array}{l}15.4 \\
9.5-21.7 \\
23\end{array}$ & $\begin{array}{c}14.7 \\
8.8-19.2 \\
24\end{array}$ \\
\hline
\end{tabular}

Some differences were observed between the two replicate trials, i.e. there was a slight decrease in adult testicular weight during the second year under $16 \mathrm{~L}$ and $8 \mathrm{~L}$. This decrease was more marked under $7 \mathrm{~L}+1 \mathrm{~L}$.

As indicated by the ranges and coefficients of variation, individual variations in testis weight were maximal when the rapid phase of testicular growth commenced. The coefficients of variation appeared relatively stable thereafter (range : 16 to 29 p. 100 from 24 to 44 weeks of age) and seemed to be unaffected by the photoschedules, insofar as these coefficients were estimated from samples involving 10 individual cockerels and might thus be liable to sample error.

\section{Daily sperm output (Experiment 2).}

a) Influence of the delay between semen collections. - It appears clear from figure 3 that, irrespective of the age of the cockerels and the photoschedule, the DSO estimated from the semen collections performed on Mondays (after 3 days of sexual rest) was about 50-60 p. 100 of the $\mathrm{DSO}_{3-5}$ estimated from the semen collections performed on Wednesdays, Thursdays and Fridays (Note that $\mathrm{DSO}_{1}=$ mean number of spermatozoa ejaculated on Monday divided by 3 . As a consequence, the standard deviation is divided by 3 as well). This difference was highly significant $(P<0.01)$ but more or less marked in the case of individual cockerels, often noted as the best semen donors. Within a week, however, there were no significant variations between the mean DSO's observed from Wednesday through Friday. 

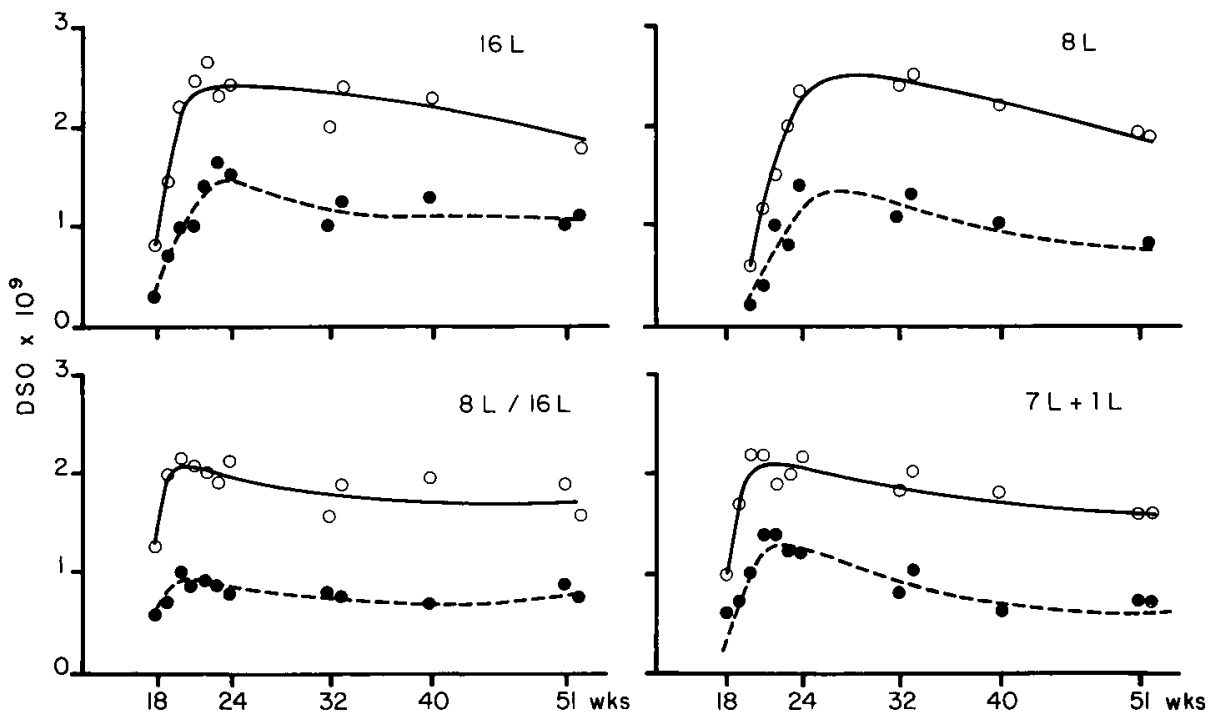

FIG. 3. - Mean DSO observed in M33 cockerels mainiained under the various experimental photoschedules. $\mathrm{DSO}_{1}$ (solid circles) was generally 50-60 p. 100 of $\mathrm{DSO}_{3-5}$ (open circles). Both followed the same general pattern as a function of age. The photoschedule influenced the age and the level at which DSO peaked. It declined slowly after 20-24 weeks of age while testis weight tended to remain constant. See table 2 for individual variations.

b) Influence of the age of the cockerels. - Irrespective of the photoschedule, the mean $\mathrm{DSO}_{1}$ and $\mathrm{DSO}_{3-5}$ steeply increased to a maximum after the first ejaculates were obtained and then gradually decreased until the end of the experiment ( 52 weeks of age). This decrease (about - 20 p. 100 from the maximum DSO to 52 weeks of age) appeared to be less marked under $8 \mathrm{~L} / 16 \mathrm{~L}$ than under the other photoschedules. It was found that similar decreases occurred in both volume and sperm concentration of the semen.

c) Influence of photoschedules. - Under $16 \mathrm{~L}, 85$ p. 100 of the cockerels were semen donors at 18 weeks of age and 100 p. 100 of the cockerels could ejaculate 2 weeks later. Both $\mathrm{DSO}_{1}$ and $\mathrm{DSO}_{3-5}$ reached a maximum at 22-23 weeks of age (1.6 and $2.6 \times 10^{9} \mathrm{spz} /$ cockerel/day, respectively).

In contrast, the $8 \mathrm{~L}$ cockerels gave no semen before 20 weeks of age, but all were donors at 22 weeks of age. Their $\mathrm{DSO}_{1}$ and $\mathrm{DSO}_{3-5}$ peaked between 24 and 32 weeks of age, i.e. later than but at the same level as the $16 \mathrm{~L}$ cockerels (1.3 and $2.5 \times 10^{9} \mathrm{spz}$, respectively).

Therefore, under constant daily photoperiods, the daylength can influence both the age at which sperm output commences and the age at which it reaches a maximum. This difference in sexual precocity was about 2 weeks in the present experiment (16L vs $8 \mathrm{~L})$. 
Under increasing photoperiods $(8 \mathrm{~L} / 16 \mathrm{~L})$, all cockerels were semen donors at 18 weeks of age and their DSO peaked at 20 weeks of age. The same results were found in $7 \mathrm{~L}+1 \mathrm{~L}$ cockerels, except that the $\mathrm{DSO}_{1}$ was higher under $7 \mathrm{~L}+1 \mathrm{~L}$ than under $8 \mathrm{~L} / 16 \mathrm{~L}$ from 20 to 32 weeks of age (respective maximum values : 1.4 and $1.0 \times 10^{9} \mathrm{spz}$ ). Therefore, increasing the daily photoperiod or using a shifting secondary photoperiod before puberty advanced the age at which the cockerels started to produce semen and became sexually mature.

Under such photoschedules, the $\mathrm{DSO}_{1}$ and $\mathrm{DSO}_{3-5}$ attained a lower maximum level (1.0 and $2.0 \times 10^{9} \mathrm{spz}$, respectively) than under constant daily photoperiods. This difference was more marked for $\mathrm{DSO}_{3-5}$ than for $\mathrm{DSO}_{1}\left(2.0\right.$ vs 2.5-2.6 $\times 10^{9}$ for $\mathrm{DSO}_{3-5}$ and 1.0 vs 1.3-1.6 $\times 10^{9}$ for $\mathrm{DSO}_{1}$, increasing and interrupted-night photoschedule vs constant daylengths, respectively). The gain in sexual precocity which could be obtained by these photoschedules (about 2 to 4 weeks as compared to constant daily photoperiods, under long or short days respectively) is therefore counteracted by a loss in the maximum level of the DSO. This is less marked or even absent, however, when considering $\mathrm{DSO}_{1}$ only in $7 \mathrm{~L}+1 \mathrm{~L}$ cockerels just after sexual maturity (21-32 weeks of age).

d) Individual variations in DSO (table 2). - Individual variations in DSO did not appear to be influenced either by the photoschedules or by the age of the cockerels after 24 weeks of age. Although minimal, there was some influence, however, of the delay between semen collections since the coefficients of variation of $D_{S O} O_{1}$ were generally higher than those of $\mathrm{DSO}_{3-5}$ at a given age $(+1$ to +26 percentage points depending on the age from 24 weeks onwards and the photoschedule). During the adult period, the coefficients of variation observed for the DSO were generally higher than those observed for testicular weight (29-58 vs 14-29 p. 100).

\section{TABLE 2}

Means, coefficients of variation (C.V.) and ranges of $\mathrm{DSO}_{1}$ and $\mathrm{DSO}_{3}$ - observed from 24 to 52 weeks of age in M33 cockerels raised under various photoschedules (the means and ranges are expressed in $10^{\circ} \mathrm{spz}$ and the C.V.'s in percentages)

\begin{tabular}{|c|c|c|c|c|c|c|c|c|c|c|c|c|c|}
\hline \multirow{2}{*}{ Photoschedule } & \multirow{2}{*}{ Parameter } & \multicolumn{9}{|c|}{ Ages in weeks } & \multirow{2}{*}{\multicolumn{3}{|c|}{52}} \\
\hline & & \multicolumn{3}{|c|}{24} & \multicolumn{3}{|c|}{32} & \multicolumn{3}{|c|}{40} & & & \\
\hline $16 \mathrm{~L}: 8 \mathrm{D}$ & $\begin{array}{l}\mathrm{DSO}_{1} \ldots \\
\mathrm{DSO}_{3-5}\end{array}$ & $\begin{array}{c}\bar{x} \\
1.49 \\
2.38\end{array}$ & $\begin{array}{c}C . V . \\
39 \\
33\end{array}$ & $\begin{array}{l}\text { Range } \\
0.6-3.1 \\
0.9-3.4\end{array}$ & $\begin{array}{c}\bar{x} \\
0.96 \\
2.02\end{array}$ & $\begin{array}{c}C . V . \\
34 \\
33\end{array}$ & $\begin{array}{c}\text { Range } \\
0.2-1.6 \\
0.8-3.3\end{array}$ & $\begin{array}{c}\bar{x} \\
1.27 \\
2.26\end{array}$ & $\begin{array}{c}\text { C.V. } \\
29 \\
24\end{array}$ & $\begin{array}{l}\text { Range } \\
0.7-1.9 \\
1.3-3.1\end{array}$ & $\mid \begin{array}{c}\bar{x} \\
1.11 \\
1.80\end{array}$ & $\begin{array}{l}C . V . \\
45 \\
39\end{array}$ & $\begin{array}{r}\text { Range } \\
0-2.7 \\
0-2.6\end{array}$ \\
\hline $8 L: 16 D$ & $\begin{array}{l}\mathrm{DSO}_{1} \\
\mathrm{DSO}_{3-5} \ldots\end{array}$ & $\begin{array}{l}1.41 \\
2.34\end{array}$ & $\begin{array}{l}48 \\
33\end{array}$ & $\begin{array}{l}0.2-3.1 \\
1.2-3.6\end{array}$ & $\begin{array}{l}1.12 \\
2.42\end{array}$ & $\begin{array}{l}39 \\
31\end{array}$ & $\begin{array}{l}0.2-2.1 \\
0.6-3.9\end{array}$ & $\begin{array}{l}0.95 \\
2.17\end{array}$ & $\begin{array}{l}36 \\
34\end{array}$ & $\begin{array}{l}0.2-1.6 \\
0.6-3.6\end{array}$ & $\begin{array}{l}0.84 \\
1.89\end{array}$ & $\begin{array}{l}41 \\
39\end{array}$ & $\begin{array}{r}0-1.8 \\
0.5-3.3\end{array}$ \\
\hline $8 L / 16 L$ & $\begin{array}{l}\mathrm{DSO}_{1} \ldots \\
\mathrm{DSO}_{3-5}\end{array}$ & $\begin{array}{l}0.85 \\
2.16\end{array}$ & $\begin{array}{l}48 \\
23\end{array}$ & $\begin{array}{l}0.1-1.9 \\
1.1-3.1\end{array}$ & $\begin{array}{l}0.75 \\
1.61\end{array}$ & $\begin{array}{l}57 \\
38\end{array}$ & $\begin{array}{r}0.12-1.2 \\
0.4-2.9\end{array}$ & $\begin{array}{l}0.82 \\
1.93\end{array}$ & $\begin{array}{l}38 \\
35\end{array}$ & $\begin{array}{l}0.2-1.8 \\
0.9-3.1\end{array}$ & $\begin{array}{l}0.83 \\
1.59\end{array}$ & $\begin{array}{l}36 \\
29\end{array}$ & $\begin{array}{l}0.2-1.2 \\
0.5-2.4\end{array}$ \\
\hline $7 L+1 L$ & $\begin{array}{l}\mathrm{DSO}_{1} \ldots \\
\mathrm{DSO}_{3}-5\end{array}$ & $\begin{array}{l}1.23 \\
2.24\end{array}$ & $\begin{array}{l}47 \\
30\end{array}$ & $\begin{array}{l}0.3-2.0 \\
1.1-3.6\end{array}$ & $\begin{array}{l}0.84 \\
1.86\end{array}$ & $\begin{array}{l}47 \\
33\end{array}$ & $\begin{array}{l}0.2-1.7 \\
0.7-3.0\end{array}$ & $\begin{array}{l}0.61 \\
1.84\end{array}$ & $\begin{array}{l}58 \\
32\end{array}$ & $\begin{array}{l}0.1-1.2 \\
0.9-2.9\end{array}$ & $\begin{array}{l}0.70 \\
1.63\end{array}$ & $\begin{array}{l}44 \\
44\end{array}$ & $\begin{array}{l}0.0-1.1 \\
0.0-3.3\end{array}$ \\
\hline
\end{tabular}


Furthermore, relatively low correlations were observed between $\mathrm{DSO}_{1}$ and $\mathrm{DSO}_{3-5}$ results $(r=0.40$ to 0.60 ) within each photoschedule for each of the different periods of semen collection. The correlations were clearly higher when comparing the numbers of sperm collected during two consecutive days ( $r=0.60$ to 0.85 ), excluding Mondays and Tuesdays.

\section{Predictions of adult DSO levels.}

The cockerels were separated into either 2 or 3 groups composed of 12-13 or 8-9 individuals each, respectively. In each group, they were ranked according to their 《 initial » $\mathrm{DSO}_{1}$ or $\mathrm{DSO}_{3-5}$ level. This « initial » level was defined at 3 different ages (18 to 21,22 to 24 or 32 to 33 weeks) and the efficiency of selection performed at each of these ages with respect to subsequent DSO levels was calculated.

Since the complete results of these different methods of selection are voluminous, only the essential features are summarized below.

a) The comparison of the mean DSO observed either in the 2 groups of $12-13$ cockerels or in the 2 extreme groups of 8-9 cockerels showed that these two methods yielded very similar results as to means and variances. Only the groups of 12-13 cockerels were therefore considered to obtain befter precision.

b) The efficiency of selection from either $\mathrm{DSO}_{1}$ or $\mathrm{DSO}_{3-5}$, judged by the subsequent mean performances of the chosen cockerels, was similar and independent of the age at which it was performed. However, using the $\mathrm{DSO}_{1}$ was less discriminating because of higher variances. Furthermore, the two methods ranked the cockerels differently. This affected about one-third of the different groups. The method using $\mathrm{DSO}_{3-5}$ was finally retained as the most discriminating and preferable one on the grounds that it used a closer approximation to the real DSO.

c) Under these conditions (12-13 cockerels per group ranked according to the $\mathrm{DSO}_{3-5}$ results), there was a strong influence of age upon the efficiency of selection as well as a certain influence due to the photoschedule (fig. 4).

When selection was performed at 18-21 weeks of age, the two groups of cockerels were not well chosen (judging by their later performance), except under the $7 \mathrm{~L}+1 \mathrm{~L}$ photoschedule $(p<0.01)$. Selections performed at either $22-24$ or $32-33$ weeks of age were satisfactory for each photoschedule $(P<0.01)$ with the exception of $8 \mathrm{~L} / 16 \mathrm{~L}$ $(0.05<\mathrm{p}<0.10)$, for which the ranking of the cockerels remained relatively stable only after 32 weeks of age. This was also observed to a lesser extent for the other photoschedules. In general, only some good « initial » semen donors became poor or non-donors, while almost no bad « initial » donors became good, except in the case of late sexual maturity. 

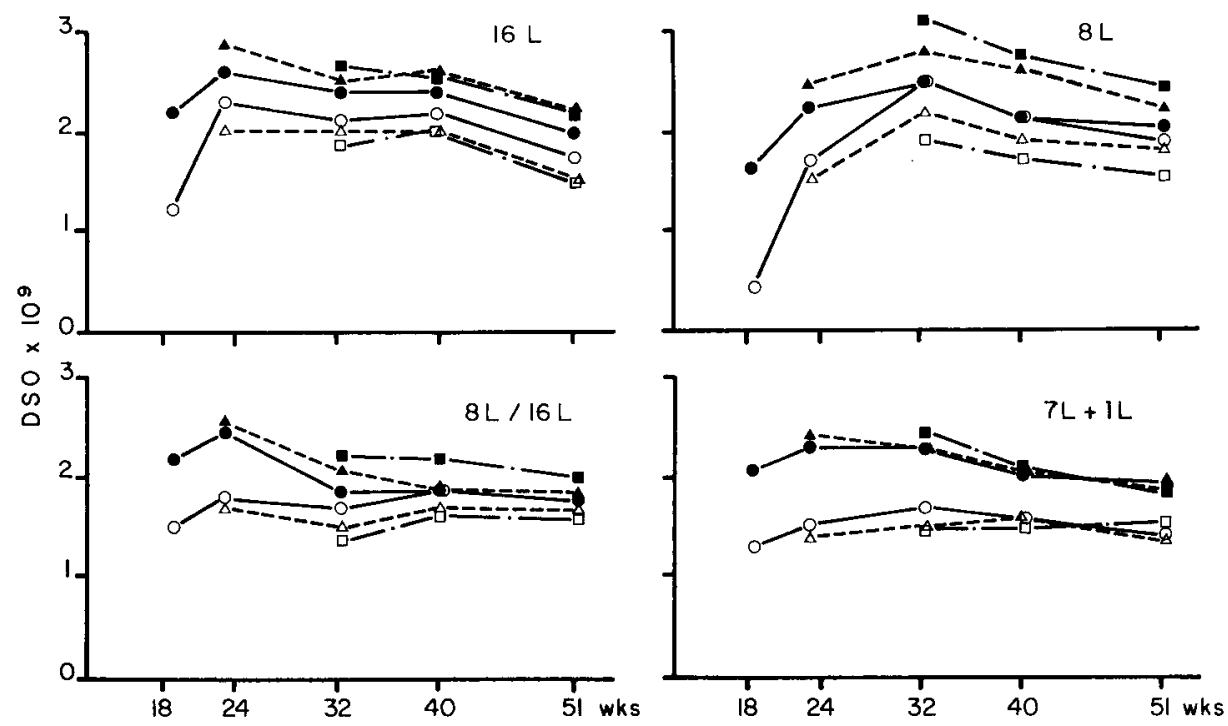

FIG. 4. - Mean $\mathrm{DSO}_{3^{-}}$observed as a function of age in groups of cockerels selected as the best (solid symbols) or the worst (open symbols) semen donors at either 18-21 weeks of age (circles), 22-24 weeks (triangles) or 32-33 weeks (squares). Note that the efficiency of this selection appears to be dependent upon the age at selection and the photoschedule. The coefficients of variation were normally between 20-35 p. 100 .

\section{Discussion and conclusions.}

1. Influence of photoschedules upon testicular development and DSO. - Under constant daily photoperiods ( $8 \mathrm{~L}$ or $16 \mathrm{~L}$ ), the age at which the rapid phase of testicular development occurred was influenced by daylength to about the same extent as the age at which the first ejaculates could be oblained from cockerels (2 or more weeks of lag between long and short photoperiods). For both photoschedules, testicular growth had terminated by 24 weeks which is approximately the age at which the DSO peaked.

In the case of the $8 \mathrm{~L} / 16 \mathrm{~L}$ photoschedule, the rapid phase of testicular development occurred two weeks earlier than under constant daily photoperiod. This was also true of the DSO.

These results are in agreement with those reported for Rhode $\times$ Wyandotte M519 cockerels (de Reviers, 1980).

In the present study, the M33 cockerels were able to maintain their mean testis weight until 44 weeks of age under $16 \mathrm{~h}$. This was not the case in either the Rhode $x$ Wyandotte M519 or the 199 Cornish type cockerels (de Reviers, 1980). Such a difference might be attributed to a genotype $x$ pholoschedule interaction. However, even in M33 cockerels, there was a definite trend for the DSO to decrease in ageing adult cockerels under $16 \mathrm{~L}$ and $8 \mathrm{~L}$ too. This trend was also apparent under $8 \mathrm{~L} / 16 \mathrm{~L}$.

The changes in both testis weight and DSO, observed under $7 \mathrm{~L}+1 \mathrm{~L}$ up to 20 weeks of age, are very similar to those observed under $8 \mathrm{~L} / 16 \mathrm{~L}$. It is still unclear whether this similarity is due to a real effect of shifting the secondary photoperiod in the 
$7 L+1 L$ photoschedule, or to the influence of the division of daylength into 2 daily photoperiods. This division can per se influence testicular development in the cockerel (Lamoreux, 1943 ; de Reviers, 1980), though to a lesser extent than in wild birds or japanese quail (Follett and Davies, 1975).

Even if the shifting of the secondary photoperiod acted in a way similar to increasing daylengths, the role of the latter, though well established in the male (de Reviers, 1980) and the female (King, 1961), is poorly understood.

A difference in adult testicular weight was observed between experiments $1 a$ and $1 b$ for the $8 \mathrm{~L}$ and $16 \mathrm{~L}$ photoschedules. This difference was more marked for the $7 \mathrm{~L}+1 \mathrm{~L}$ photoschedule. Its origin is uncertain and thus it is difficult to draw any firm conclusions as to a difference in adult testicular weight between the $8 \mathrm{~L} / 16 \mathrm{~L}$ and $7 \mathrm{~L}+1 \mathrm{~L}$ photoschedules. The same difficulty arises for the DSO results, for adult DSO $\mathrm{D}_{1}$ was higher for $7 \mathrm{~L}+1 \mathrm{~L}$ than for $8 \mathrm{~L} / 16 \mathrm{~L}$ while $\mathrm{DSO}_{3-5}$ was similar for both photoschedules. More information is therefore required to draw a definite conclusion.

2. DSO results. - The influence of sexual rest upon the DSO is once more confirmed by a comparison of $\mathrm{DSO}_{1}$ and $\mathrm{DSO}_{3-5}$ as they were estimated in the same cockerels. As far as the mean DSO is concerned, it appears, according to the present results and those previously reported by Burrows and Titus (1939), Swierstra and Strain (1964), de Reviers (1972a) and McDaniel and Sexton (1977), that the daily sperm production of the testes is better exploited by the use of frequent semen collections which also improve the quality of ejaculated sperm (Petitjean, 1970 ; de Reviers and Petitjean, 1973). In other words, insufficiently frequent semen collections lead to the use of excess breeders, and this has immediate consequences upon the cost of the offspring.

However, the difference between $\mathrm{DSO}_{1}$ and $\mathrm{DSO}_{3-5}$ was more or less marked depending on the individual. This may have resulted from differences in ability to store spermatozoa in the deferent ducts (de Reviers, 1972b) and might at least partly explain the relatively low correlations $\left(0.4\right.$ to 0.6 ) observed between $\mathrm{DSO}_{1}$ and $\mathrm{DSO}_{3-5}$. As a consequence of this, performing semen collections either at frequent or infrequent intervals gives rise to discrepancies between the ranking of cockerels oblained in both cases, because this ranking mainly involves sperm production in the first case, and extragonadal sperm reserves in the second.

In the present results, individual variations in the DSO, were more marked than those relating to testicular weight. This can be explained by individual differences in the spermatogenetic yield (de Reviers, 1971), and by the individual capabilities of cockerels to store semen and respond to the massage method of semen collection. However, despite this variation, selecting cockerels based on their DSO prior to their use as breeders is nonetheless feasible according to the present results, except in the case of the $8 \mathrm{~L} / 16 \mathrm{~L}$ photoschedule.

The age at which this selection was efficient was photoschedule-dependent. For $7 \mathrm{~L}+1 \mathrm{~L}$, the best results were obtained as early as 18-21 weeks of age, while discrimination could be made between the future high and low semen producers at 22-24 weeks for $16 \mathrm{~L}$ and $8 \mathrm{~L}$. For $8 \mathrm{~L}$, this discrimination was sharper at $32-33$ weeks of age. This indicates that selection is, in fact, feasible at the end of testicular growth, i.e. in sexually mature cockerels. Prior to this stage, the lower efficiency of selection is probably due to 
differences in the sexual precocity of cockerels rather than to differences in their final testicular weight.

The efficiency of this selection is, however, limited by the crossover of some cockerels from one group to the other. In other words, there is considerable individual variation in the rate at which the DSO declines in the adult. The understanding of this, as well as of the individual variations in testicular weight and DSO observed at the end of testicular growth, merit further study. Investigation of the endocrinological mechanisms involved may prove a fruitful method of approaching this problem.

Workshop on "Avian male reproduction 》 Nouzilly, France, June 1980.

Acknowledgements. - This work was partly supported by a grant from the Délégation Générale d̀ la Recherche Scientifique ef Technique, aide no 78-7-2747.

Résumé. Chez le coq M33, la phase rapide de la croissance testiculaire et le début de la production de spermatozoïdes sont rendus plus précoces sous l'influence soit de jours croissants soit de photopériodes fractionnées, et sont au contraire retardés par les jours courts constants $(8 \mathrm{~L})$. Les jours longs constants $(16 \mathrm{~L})$ donnent des résultats intermédiaires. Dans cette souche, le poids testiculaire moyen est maintenu pendant la période adulte alors que le nombre de spermatozoïdes éjaculés diminue graduellement.

Les variations individuelles du nombre de spermatozoïdes éjaculés sont plus importantes que celles du poids testiculaire. Ces variations ne paraissent pas influencées par les programmes d'éclairement. Les différences observées pour le nombre de spermatozoïdes éjaculés suivant que les coqs sont bons ou mauvais donneurs de sperme à la fin de leur développement testiculaire, restent relativement stables par la suife, excepté chez les coqs soumis aux jours croissants. Ce résultat permet donc de déterminer les meilleurs donneurs de sperme vers 18-21 ou 22-24 semaines d'âge, suivant le programme d'éclairement, c'est-àdire avant leur utilisation comme reproducteurs.

\section{References}

AMANN R. P., 1970. Sperm production rates, vol. 1, 433-482. In The testis, A. D. JOHNSON, W. R. GOMES, N. L. VAN DEMARK. Acad. Press.

BRILLARD J. P., REVIERS M. de, 1981. Testis development and daily sperm output in guinea-fowl raised under constant daily photoperiods. Reprod. Nutr. Dev., 21, 1105-1112.

BURROWS W. A., QUINN J. P., 1937. The collection of spermatozoa from the domestic fowl and turkey. Poult. Sci., 16, 19-24.

BURROWS W. A., TITUS H. W., 1939. Some observations on the semen production of the male fowl. Poult. SCi., 18, 8-10.

FOLLETT B. K., DAVIES D. T., 1975. Photoperiodicity and the neuroendocrine control of reproduction in birds. Symp. zool. Soc. London, 35, 199-224.

KING D. F., 1961. Effects of increasing, decreasing and constant lighting treatments on growing pullets. Poult. Sci., 40, 479-484.

LAMOREUX W. F., 1943. The influence of different amounts of illumination upon the production of semen in fowl. J. exp. Zool., 94, 73-95.

MCDANIEL G. R., SEXTON T. J., 1977. Frequency of semen collection in relation to semen volume sperm concentration and fertility in the chicken. Poult. Sci., 56, 1989-1993. 
PETITJEAN M. J., 1970. Résultats expérimentaux sur la subfertilité liée à la crête rosacée chez le coq. XIVe Congr. mond. Avic., Madrid, 2, 313-318.

PETITJEAN M. J., GUILLOT P., RICARD F. H., 1978. Motilité du sperme des coqs et fertilité des troupeaux dans une souche de poules Wyandotte à crête rosacée. XVIJe Congr. mond. Avic., Rio de Janeiro, 815-820.

REVIERS M. de, 1971. Le développement testiculaire chez le coq. II. Morphologie de l'épithélium séminifère et établissement de la spermatogenèse. Ann. Biol. anim. Biochim. Biophys., 11, 531-546.

REVIERS M. de, 1972a. Evaluation de la production de spermatozoïdes chez le coq. Ann. Biol, anim. Bioch. Biophys., 12, 13-18.

REVIERS M. de, 1972b. Evaluation des réserves spermatiques dans les voies déférentes du coq. Ann. Biol. anim. Bioch. Biophys., 12, 5-11.

REVIERS M. de, 1980 . Photoperiodism, testis development and sperm production in the fowl. 9th int. Congr. anim. Reprod. \& A.I., II, 519-526.

REVIERS M. de, PETITJEAN M. J., 1973. Effets du gène de nanisme dw sur la production de spermatozoïdes chez le coq en croissance. Ann. Sél. Gén. anim., 5, 313-321.

SWIERSTRA E. E., STRAIN J. H., 1964. Sperm output of White Leghorn roosters ejaculated daily or every other day for eight weeks. Poult. Sci., 43, 1368. 